\title{
Post-War Development and Women's Empowerment in Eastern Sri Lanka: A Case Study of Batticaloa District in Eastern Province
}

\author{
Dr. A. Rameez \\ Senior Lecturer in Sociology, \\ South Eastern University of Sri Lanka, \\ Sri Lanka
}

DOI: https://doi.org/10.36941/ajis-2020-0o68

\begin{abstract}
The civil war in Sri Lanka had caused enormous impacts on the physical as well as infrastructure development of Eastern Province. Since the end of war in 2009, the province has immensely benefitted from the state and non-state sectors, particularly in the sphere of women empowerment in terms of their livelihood, education, health, etc. Although, many previous studies have delved into a number of post-war development interventions in the province, it failed to explore the dimension of women's empowerment. Using both qualitative as well as quantitative methods, this study specifically explores the impacts of socioeconomic development initiatives on women's empowerment in the post war context. The findings show women received much support such as housing assistance, dry rations, livelihood assistance, micro-credit loans and psycho-social counselling from state and non-state sectors including NGOs, and UN organizations in the post war period in the Batticaloa district of Eastern Province and such supports have largely been effective as it contributed to women's empowerment. Nevertheless, such supports have significantly dried up in recent times with priorities of state and non-state sectors being shifted. Thus, it is crucial for state and non-state sectors to focus on the empowerment of women in future, especially enhancing their capacity in terms of their knowledge and skills, and providing financial assistance for their self-employment on a soft loan basis or under grant schemes.
\end{abstract}

Keywords: women empowerment, civil war, post-war development, state and non-state sectors, soft loans

\section{Introduction}

With the government's military victory over Liberation Tigers of Tamil Ealam (LTTE) in May 2009, the civil war that lasted for about 3 decades in Sri Lanka ended having freed the Northern and Eastern part of the country from the grip of the LTTE. In such a context, the issue of post-war reconstruction and rebuilding of Northern and Eastern province of the country came to the fore since then (Thalpawila, 2016). The literature that deals with post war peace building and reconstruction has lucidly emphasized on the urgent need of peace building and post war reconstruction as pivotal steps for countries which faced long term civil war (United Nations, 2009). Moreover, it is also increasingly emphasized that the first few post war years are critically important for restoring peace and reconciliation in the country.

The Eastern province of Sri Lanka consisting of three districts, namely Trincomalee, Batticaloa and Ampara is one of the severely affected areas of civil war. It inflicted huge impacts on infrastructure, livelihood of people and social and economic development in the province. The end of war has generated a diverse range of opportunities for improving socio-economic fortunes of Eastern province in the sphere of economy, education, health, infrastructure, women empowerment, livelihood development, peace building, psycho social efforts, etc. by the state and non-state sector 
organizations in the Eastern province where Tamils and Muslims are living together. It is notable that in the post war context, the government implemented a two-pronged regional development strategy targeting both short- and medium-term objectives to address certain socio-economic issues confronting the Northern and the Eastern of Sri Lanka. One of which that was implemented in the Eastern province was the regional development project called 'Reawakening of the East' (Nagenahira Navodaya) carried out to restore and enhance the life of the people in the Eastern Province with effect from July 2007. The target of this regional development programme was to provide humanitarian relief and physical reconstruction by the Ministry of Economic Development with the assistance of the international community, UN agencies as well as international and local NGOs. The early recovery areas of humanitarian relief focused on de-mining, resettlement of IDPs, restarting of agriculture and renovation of irrigation facilities; further work involved restoration/ renovation of roads, power and energy, providing livelihood support, fisheries and livestock development, education, civil administration and health and sanitation (Thalpawila, 2016).

In such a backdrop, an allocation of 54,827.39 million Rs was made on socio-economic sectoral development in Batticaloa district from 2009 to 2013 (Planning Division: Batticaloa Kacheri,2014); roads and bridges, and health sector were the major areas of sectoral development that received a significant contribution of allocation in terms of post war reconstruction in the province (Sutharsan, 2014).

The development interventions by the state and non-state sectors including the NGOs prioritized some projects like empowering women in terms of their livelihood, education, selfemployment, health sector, etc. Although many previous studies focused on a number of post-war development interventions implemented in various parts of the Eastern Province (Ismail, 2013; Sutharsan, 2014), it failed to explore the dimension of women's empowerment as a result of socioeconomic development interventions implemented by various agencies in the post war context of Eastern Sri Lanka, particularly in Batticalao district and how it socially, economically, politically and educationally empowered women in the district. Thus, an empirical study focusing on the impact of socio-economic development in the post war Sri Lanka on women empowerment is critically important and deserves to be analysed further. Moreover, much of the literature that dealt with post war reconstruction and peace building process in Northern and Eastern province of Sri Lanka employed secondary sources of information for its data collection and analysis. However, this study uses both secondary and primary sources of information for data collection and analysis.

Thus, the aim of the study is to explore the impacts of socio-economic development interventions on women's empowerment in the post war context in Batticaloa district of Eastern Sri Lanka.

The following are the objectives of the study:

1) To assess the number of socio-economic development interventions that aimed at empowering women in terms of their livelihood, education, self-employment, health, etc. in the post-war context in Batticaloa district of Eastern Sri Lanka.

2) To investigate the impacts of such interventions on women's empowerment.

3) To examine the sustainability of such interventions carried out in the district.

\section{Research Methodology}

This study is based on both qualitative and quantitative research methods. The qualitative and quantitative data were gathered by using primary and secondary sources. The secondary data were collected through published books, research reports, journals and online archives. Particularly, the data on the number of socio-economic development projects, particularly projects on women's empowerment carried out by the government and NGOs were collected from secondary sources, i.e. from the Kacheri of Batticaloa (District Administrative Office) and NGOs consortium from the district.

The primary data were collected in several field visits in the district. The research was commenced with a pilot visit to the research locations to gain an insight into the local socioeconomic and political context. In such a way, observation is a method employed in this exercise of initial data collection process. 
The next source of data was collected from fifteen (15) in-depth interviews with local stakeholders to know the different perceptions on the impacts of socio-economic development projects by various agencies on women's empowerment in the Batticalao district of Eastern province in the post war context. Women in the districts, Women Development Officers of Divisional Secretariats, and civil society members were interviewed for this purpose. Of which, 10 Tamils and 5 Muslims were interviewed, while 4 focus group discussions conducted in Tamil dominated areas and 2 focus group discussions conducted in Muslim dominated areas in the district.

The next source of data was collected from six (6) focus groups discussions in selected areas of the district worst affected by civil war with participants representing from various segments of people including social activists, women' activists, civil society representatives, government servants, etc. Of which, four (4) focus group discussions were conducted in Tamil dominated areas such as Thoppikkala, Ollikolam, Kokkatticholai and Kaluwanchikkudy and two (2) in Muslims dominated areas like Kattankudy and Eravur in the district.

The next source of information is collected from a household survey employed in the district to explore the impacts of post-war socio-economic development initiatives on women's empowerment in Eastern Sri Lanka. 500 questionnaires were distributed to gather quantitative data among the households in the district. The questionnaire was translated into local language and a pilot survey was also conducted as mentioned above. Findings from the pilot survey and suggestions extended by the researchers were taken into account in the finalization of the questionnaire.

\subsection{Sampling and Data Analysis}

The stratified and random sample selection strategy was used in order to ensure that the selected respondents represent the entire population and to avoid biases. The following table shows the disaggregated sample distribution in the district of Batticaloa of Eastern province in terms of ethnicity (Tables 1).

Table 2.1.1: Sample distribution on the basis of ethnicity

\begin{tabular}{|c|c|c|c|c|c|c|c|}
\hline \multirow{2}{*}{ District } & \multicolumn{7}{|c|}{ Population and Samples } \\
\hline & Muslims & Tamils & Sinhal & & Others & Total Population & Total Samples \\
\hline Batticaloa & \begin{tabular}{l|l}
154,197 & 132 \\
\end{tabular} & 424,199 & 3,303 & 03 & \begin{tabular}{|l|l|}
4,902 & 04 \\
\end{tabular} & 586,601 & 500 \\
\hline
\end{tabular}

The sample distribution of quantitative survey based on sex, age and ethnicity is discussed below. Sample distribution of 500 questionnaires employed for this study in the district is given below in the figure based on sex.

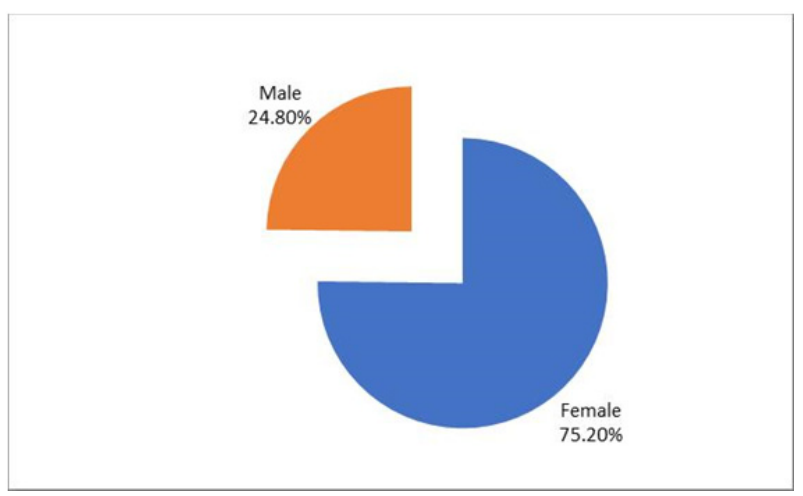

Figure 2.1.1: Sample distribution based on sex 
The above table and figure highlight that higher percentage of women respondents was selected as sample due to the significance of the research that has much to do with women's empowerment. Moreover, it was more an unintentional outcome of doing survey house to house, as women were at home at the time of carrying out the survey.

Minimum age of those who took part in the survey was 15 , while maximum age of those who took part in the survey was 85 . Literacy level of respondents who took part in the survey ranges between primary and secondary level of education and majority of respondents were married at the time of survey done in the research area. Similarly, majority of the respondents who took part in the survey were housewives and farmers.

Moreover, the completed questionnaires were checked and entered into SPSS database designed for the survey. Before starting the analysis process, the dataset was weighted in order to reflect actual geographical and ethnic proportion. Qualitative data were also analysed using descriptive method.

\section{Research Area}

This survey was done in Batticaloa district in eastern province of Sri Lanka (See: Map 3.1). The district is positioned in the east coast of Sri Lanka and bounded in the east by the Bay of Bengal, North by the Northern Province, West by the North Central and Central Provinces and South by the Uva and Southern Provinces (Planning Secretariat, Batticaloa Kacheri, 2018).

The district has two major ethnic communities of country namely Muslims and Tamils and others like Sinhalese, smaller minority in the district. In Batticaloa, the Tamils are the majority in relation to the Muslims. Total population of the district based on ethnicity is given in the above section 2.1.1. Moreover, the map of Batticaloa district is shown below.

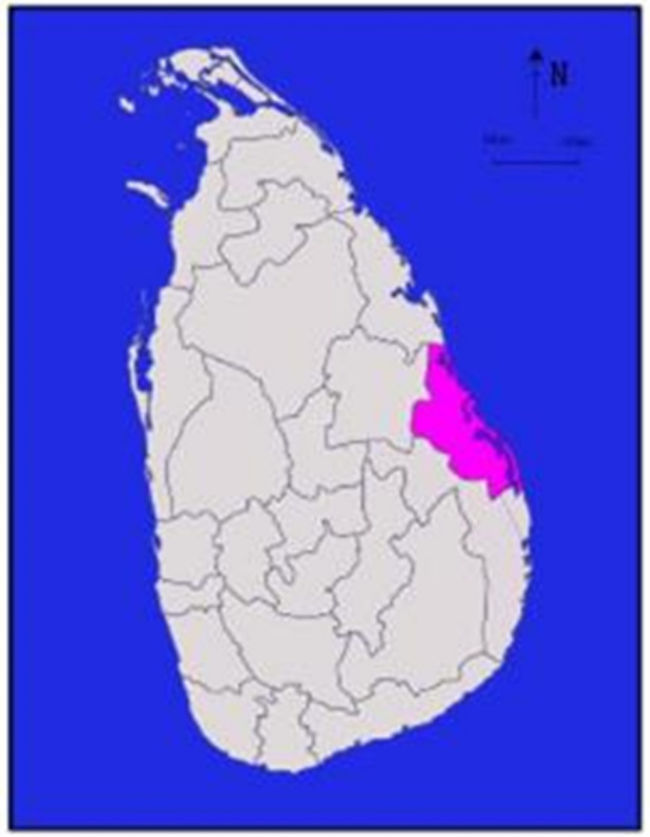

Map 3.1: The Map of Batticaloa District

Source: http://www.ep.gov.lk/ 
The district is primarily agricultural area of the country and has all kinds of grains and cereals and fruits and vegetables, making any investments in this sector profitable. The district also contributes to national fish production. Large scale maize cultivation with hybrid seeds and contractual marketing has also been recorded in the district. Availability of large amounts of fertile and virgin lands, coupled with cheap labor, adds manifold beneficial dimensions to the agriculture sector (Planning Secretariat, Batticaloa Kacheri, 2015).

Since large areas of lands are available in the district for mega development projects, it is an ideal place to set up business ventures like automobiles, pharmaceuticals, steel, light weight machinery etc. The industrial sectors like textile factories (apparel industry) have mushroomed in the recent times in the district. There are paper factories located in the district too.

The district is also endowed with a vast stretch of beach, making it an excellent hotspot for tourists from across the world. With many seaside resorts and hotels located near lagoons and beaches, tourism industry is booming. Pasikudah, and Kalkudah, are very popular beach resorts. Tourism industry in the district has flourished not because of its historical and religious sites, but because of its other natural attractions such as coral reefs.

More importantly, the district was badly affected by both the civil war and Tsunami and as such investments in infrastructure and utility services in the district such as Railways, Aviation, Water Supply, Sewerage and Drainage Systems, Ports and Harbors, etc. have suffered a heavy setback. However, the Tsunami in 2004 and the civil war that lasted for over three (3) decades in the country set the platform for the government, Non-Governmental Organizations(NGOs), and other UN organizations to engage in socio-economic and educational development initiatives in the post war scenario with the sole intention of improving the living condition of the people in the district.

\section{Significance of the Study}

As this study focuses on the impacts of development initiatives on women's empowerment, the future relevance and the findings of the study will be of immense use to the government as well as NGOs to design their future development projects. It will provide useful insight for development partner coordination and possibly also for government of Sri Lanka for the implementation of their annual socio-economic development in the area based on Action Plan.

A key outcome of this study is the ability to inform future policy making based on a comparative analysis undertaken through this study of interventions, their impacts and long-term sustainability.

\section{Results and Discussion}

This section shows the results derived from the survey and engages in a discussion based on the results. Thus, it focuses on the dimension of living condition of people including women in the district prior to war, impacts of war on people, the level of resilience of people affected by war. Then, it deals with the support provided by both the state and non-state sectors to the victims affected by the civil war in the district, particularly on women empowerment. A special focus has been given whether or not such support continues to be provided by the same agencies or organizations to the people even now and how far it has been effective to the women empowerment in the district in the post war context.

\subsection{Status of people and women before the civil war}

It is important to examine the level of wealth of the people in the district before the war, so that it can be compared with the post war situation. Thus, the level of wealth of people before the war in the district based on the survey is given below 
Table 5.1.1: Level of wealth prior to war

\begin{tabular}{|l|c|c|c|}
\hline Level of wealth before the war & Tamils & Muslims & Overall \\
\hline Well-off & $31.88 \%$ & $1.86 \%$ & $33.75 \%$ \\
\hline Somewhat rich/Well-off & $9.52 \%$ & $12.63 \%$ & $22.15 \%$ \\
\hline Monthly salaried (state jobs) & $1.24 \%$ & $2.90 \%$ & $4.14 \%$ \\
\hline Daily salaried(labour) & $23.60 \%$ & $13.25 \%$ & $36.85 \%$ \\
\hline Others & $\mathbf{2 . 9 0} \%$ & $0.21 \%$ & $3.11 \%$ \\
\hline Grand Total & $\mathbf{6 9 . 1 5} \%$ & $\mathbf{3 0 . 8 5} \%$ & $\mathbf{1 0 0 . 0 0 \%}$ \\
\hline
\end{tabular}

Level of wealth of the survey respondents before the war is explained in table 5.1.1. Accordingly, $33.75 \%$ of them were well off, while $36.85 \%$ of were doing daily salaried jobs like labours. Only $4.14 \%$ of them were doing monthly salaried jobs (state jobs) before the war. Therefore, it can be seen that a significant number of people were financially well-off, despite being engaged in daily salaried jobs.

The table also explains the level of wealth of the survey respondents before the war by ethnicity. Among Tamils, $31.88 \%$ of them were financially well-off before the war and $9.52 \%$ of them were somewhat rich, Among Muslims, 12.63\% of them were somewhat rich/well-off. Overall, majority of them-both Muslims and Tamils $(36.85 \%)$ were doing daily salaried, while negligible number of people was engaged in monthly salaried jobs. The qualitative data obtained from respondents in the district also shows that majority of the people-both Tamils and Muslims were leading a decent life prior to the war with adequate amount of income required for their life styles. However, the respondents in the interviews and focus group discussions agree that Batticaloa is one of the least educated districts in Sri Lanka and thus people doing monthly salaried jobs (government jobs) are relatively poor.

Economic status of women in terms of their living conditions is not satisfactory. The following figure strongly portrays it.

\section{Were women working in your household before the war?}

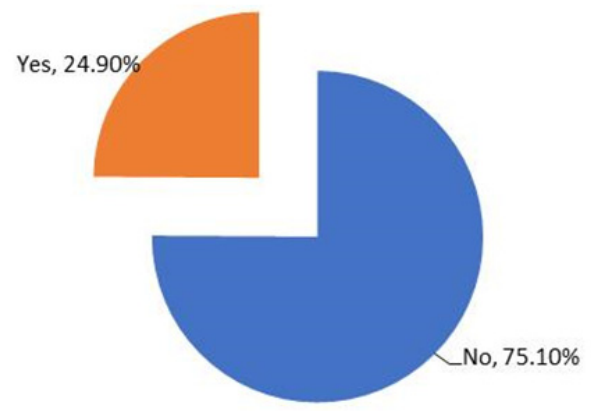

Figure 5.1.1: Economic status of women prior to war

The above figure illustrates that only $24.90 \%$ of women in the household were working before the war, while a large majority of women $(75.10 \%)$ in the household remain jobless, i.e, looking after the household chores. Among those who were working (24.90 \%) before the war, most of them (58.72 \%) were self-employed (Tamils: $27.52 \%$ and Muslims: $17.43 \%$ ). About $25.69 \%$ and $12.84 \%$ of women were employed in government as well as private sectors respectively. 
Qualitative data such as interviews and focus group discussions also suggest that majority of women in the district were not doing anything, i.e. remained jobless due to poor literacy and cultural barriers. A woman respondent state:

"We were not meant to do a job or engage in self-employment as we were compelled to look after our family and raise our kids. There were some cultural barriers for women doing job too or engage in selfemployment" (Interview -01).

The above perspective was largely corroborated by qualitative data obtained in the FGDs where emphasis was given to women representing both Tamil as well as Muslim community were meant to look after their domestic chores at the expense of doing jobs outside. This has been the culture among the people for some time. However, the respondents in the FGD have also noted that this trend is fast eroding with a greater number of young women in the district now showing much propensity to further their studies or engage in self-employment due to rising cost of living and other influences.

When it comes to the ethnic breakdown of working condition of women in household prior to war, economic status of Tamil women compared to Muslim women is far worse. This can be clearly illustrated in the following figure.

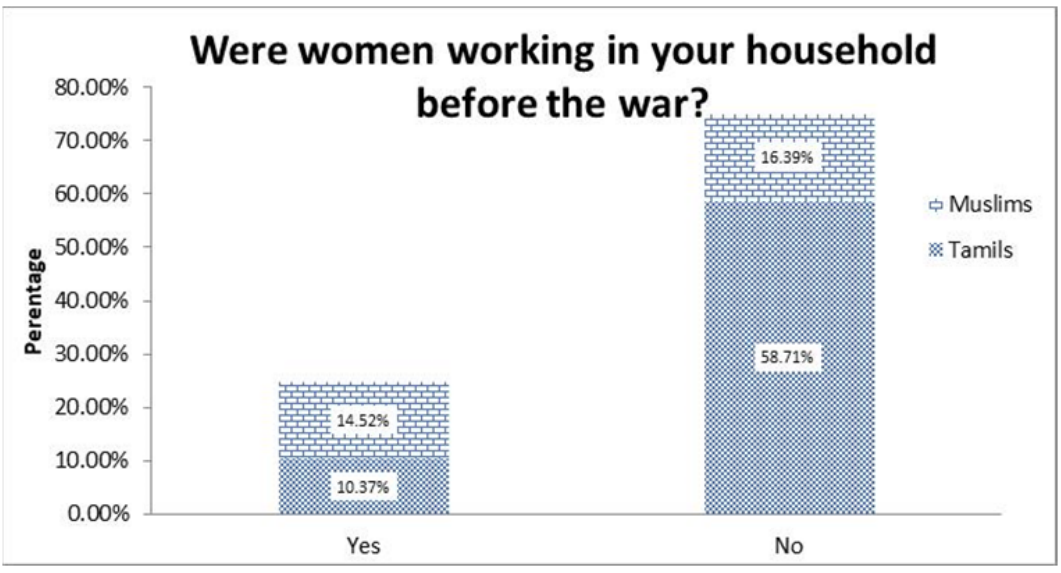

Figure 5.1.2: Economic status of women by ethnicity prior to war

As can be seen, $58.71 \%$ of Tamil women in the household were not working (compared to Muslim women $16.39 \%$ ) and only $10.37 \%$ of Tamil women were working prior to war. Thus, their economic condition is not satisfactory. On the other hand, the economic status of Muslim women is relatively good in the district prior to war, though they were the minority in the district. This can be substantiated with the qualitative data obtained from the district. Respondents of interviews claim:

"As women, we were confined to our houses engaging in household activities such as cooking, washing, raising kids and other works at home and thus were required to do jobs outside. This is the trend among the majority of women in our village too" (Interviews 02)

"As Muslim women, we were also meant to be at home doing daily household chores, however, our husband allowed us at some point to engage in self-employment initiatives like preparing hoppers or string hoppers to meet the rising cost of living on our family" (Interviews 03)

As is clear from the above responses, the requirement of women in the district was to primarily look after their household activities at the expense of engaging in jobs outside. However, the condition of 
Tamil women in the district, as we show, is far worse than the Muslim women in terms of their livelihood status.

\subsection{Impact of civil war on people in the district}

As we have seen the economic status of people and women in the district prior to war, it would be prudent to explore the effect of war on the people in the district.

Table 5.2.1: Impact of civil war on participants

\begin{tabular}{|l|c|c|c|}
\hline Were affected by civil war & Tamils & Muslims & Overall \\
\hline Not at all & $4.36 \%$ & $13.69 \%$ & $\mathbf{1 8 . 0 5 \%}$ \\
\hline To some extent & $34.02 \%$ & $13.28 \%$ & $47.30 \%$ \\
\hline Very much so & $30.71 \%$ & $3.94 \%$ & $34.65 \%$ \\
\hline Grand Total & $\mathbf{6 9 . 0 9} \%$ & $\mathbf{3 0 . 9 1} \%$ & $\mathbf{1 0 0 . 0 0 \%}$ \\
\hline
\end{tabular}

The above table depicts the effect of civil war on participants. Accordingly, most of the participants $(47.30 \%)$ were affected by the civil war to some extent, while $34.65 \%$ of them were seriously affected by the war. Only $18.05 \%$ of the participants were not affected at all. The survey further shows how the survey participants affected by the civil war. $27.31 \%$ of respondents lost their assets like properties, lands, house etc. in the civil war, while most of the respondents (51.24\%) lost more than one aspect of losses due to the war. About 3.16\% of them were lost lives of close relatives and $2.48 \%$ suffered mental and psychological trauma in the civil war.

Moreover, Tamils were the major victims of civil war (34.02 \% to some extent and $30.71 \%$ very much so) compared to Muslims in the district. As the war waged between the government forces and Liberation Tigers of Tamil Ealam (LTTE) representing the Tamil community in North and East, it is conceivable that the innocent Tamils were at the receiving end, though they were not part of it. On the contrary, only few percentages of Muslims (13. $28 \%$ to some extent and 3.94\% very much so) were affected by the war, as they were living side by side with Tamils in the district.

Qualitative data also suggests that all the people regardless of ethnic, class or caste differences in the district were seriously affected by the protracted civil war incurring heavy losses on their lives, properties and other assets. However, ethnic dimension of serious effect of civil war varies from Tamil to Muslim community in the district. Respondents in the qualitative data claim that the Tamils were the worst affected community in the civil war with the LTTE representing the Tamils. As such, they were at the receiving end of the government military forces. A respondent from Tamil community said in the interview:

"I lost my husband and suffered economically and socially due to the war. The mental trauma that our family underwent due to the impacts of war is unprecedented and the worry is that it still haunts us" (Interview 04).

The above is an excerpt of the interview with a Tamil respondent in the district whose plight of war is unfathomable. This is worse in the case of those Tamil living in the villages in the district where their infrastructure, housing and other facilities are poor. The view that the Tamils, compared to Muslims, were the worst affected community in the district was endorsed by many in the interviews and FGDs. However, a respondent from Muslim community contrasted the view:

"It is true that Tamils were affected in the civil war; however; we were also subjected to suppression and oppression at the hands of LTTE and sometimes government military forces. To make matters serious, hundreds of our brothers were butchered by the LTTE at the mosque while they were prostrating/praying Isha prayer in 1990s. This is unforgivable and ever memorable to us" (Interview 05). 
As can be seen, the above is a throwback of war from a respondent representing Muslim community in the district. It is clear that both Tamils and Muslims suffered immensely due to the protracted war. However, it is worth emphasizing the fact that the Tamils were the worst hit community as they were alleged to have associated with the LTTE and thus experienced the hardship at the hands of government military forces.

\subsection{Restoring the lives from civil war}

It is crucial to restore the lives of affected people due to war that lasted for about three decades in the country. As such, the following table depicts the level of restoration of those affected people by the civil war.

Table 5.3.1: Level of restoration of lives by affected people of civil war

\begin{tabular}{|l|c|c|c|}
\hline Row Labels & Tamils & Muslims & Overall \\
\hline Very much so & $60.84 \%$ & $4.82 \%$ & $65.66 \%$ \\
\hline To some extent & $24.10 \%$ & $6.02 \%$ & $30.12 \%$ \\
\hline Not at all & $3.61 \%$ & $0.60 \%$ & $4.22 \%$ \\
\hline Grand Total & $\mathbf{8 8 . 5 5} \%$ & $\mathbf{1 1 . 4 5} \%$ & $\mathbf{1 0 0 . 0 0} \%$ \\
\hline
\end{tabular}

Among those who were seriously affected by the civil war, majority of the respondents (65.66\%) stated that they were able to restore their lives into normalcy very much, while $30.12 \%$ of them stated that they were able to do so to some extent. Interestingly, of those affected, $84.94 \%$ of Tamil respondents $(60.84 \%$ and $24.10 \%)$ stated that they were able to restore their lives into normalcy, despite being affected by the civil war seriously. This is a positive trend as far as the Tamil people are concerned and can be contrasted drastically with Muslims who were less affected by the civil war in the district. The trend of recovery and resilience of people has largely been highlighted by many in the qualitative data in the post-war period.

\subsection{Support/Assistance received from government and other agencies}

The people affected by civil war have received many assistances from a number of agencies. Therefore, it is essential to explore what kind of support they received and from which sources they received.

Table 5.4.1: Assistance received in the post war period

\begin{tabular}{|l|c|c|c|}
\hline $\begin{array}{l}\text { Did you receive any assistance from any } \\
\text { other agencies in the post war period }\end{array}$ & Tamils & Muslims & Overall \\
\hline Yes & $57.43 \%$ & $21.89 \%$ & $79.32 \%$ \\
\hline No & $12.65 \%$ & $8.03 \%$ & $20.68 \%$ \\
\hline Grand Total & $\mathbf{7 0 . 0 8} \%$ & $\mathbf{2 9 . 9 2} \%$ & $\mathbf{1 0 0 . 0 0} \%$ \\
\hline
\end{tabular}

Among the respondents, $79.32 \%$ of them received assistance from any other agencies in the post war period. As can be seen, this overall $79.32 \%$ includes $57.43 \%$ Tamils and $21.89 \%$ of Muslims. They received such support from different agencies/institutions. Of which, majority of the respondents $(71.22 \%)$ received the support from government sector, while the respondents also received the support from NGOs $(62.79 \%)$ and UN Organizations too (27.03\%). This can also be shown in a table below. 
Table 5.4.2: The agencies that provided support/assistance to the people in the post war period

\begin{tabular}{|l|c|c|c|}
\hline Institutions/Agencies & Tamils & Muslims & Overall \\
\hline Government sector & $46.51 \%$ & $\mathbf{2 4 . 7 1} \%$ & $71.22 \%$ \\
\hline UN Organizations & $12.79 \%$ & $\mathbf{1 4 . 2 4} \%$ & $\mathbf{2 7 . 0 3} \%$ \\
\hline NGOs & $40.70 \%$ & $\mathbf{2 2 . 0 9} \%$ & $62.79 \%$ \\
\hline CBOs/Private organizations & $\mathbf{0 . 2 9} \%$ & $5.23 \%$ & $5.52 \%$ \\
\hline Philanthropists & - & $8.72 \%$ & $8.72 \%$ \\
\hline Others & $3.20 \%$ & $0.29 \%$ & $3.49 \%$ \\
\hline
\end{tabular}

The respondents in the district have received many supports from the above-mentioned agencies for their economic recovery. It is also significant that Muslims have received support from philanthropists though negligible. However, such trend is not conspicuously missing among the Tamils. This can be shown in a table given below.

Table 5.4.3: Type of assistance received from any agencies

\begin{tabular}{|l|c|c|c|}
\hline Assistance & Tamils & Muslims & Overall \\
\hline Housing & $29.74 \%$ & $19.23 \%$ & $48.97 \%$ \\
\hline Livelihood assistance & $18.72 \%$ & $14.62 \%$ & $33.33 \%$ \\
\hline Dry rations & $25.64 \%$ & $12.56 \%$ & $38.21 \%$ \\
\hline Psycho-social counselling & $3.85 \%$ & $14.87 \%$ & $18.72 \%$ \\
\hline Micro-credit loans & $17.18 \%$ & $11.28 \%$ & $28.46 \%$ \\
\hline Others & $13.85 \%$ & $1.54 \%$ & $15.38 \%$ \\
\hline
\end{tabular}

Type of assistance received from the agencies by the respondents is explained in above table indicates that majority of them-both Tamils and Muslims (48.97\%) received housing assistance, dry rations (38.21\%), livelihood assistance (33.33\%), micro-credit loans $(28.46 \%)$ and psycho-social counselling $(18.72 \%)$. Respondents stated that other kinds of assistance they received such as Samurthi loans and temporary houses under the "other" category. It is interesting that Tamils received all kinds of support than Muslims, except in the domain of psycho-social counselling in which the Muslims received $14.87 \%$ support.

Qualitative data obtained from the field works also suggests that Tamil and Muslim people affected by the civil war in the district have received support from many agencies, primarily from the government and NGOs in the post war context. Secondary data obtained from Planning Division of Kacheri Batticaloa also shows that the people have received much support from the government under the regional development project called 'Reawakening of the East' (Nagenahira Navodaya) which was implemented by the government under the funding of UN agencies and NGOs (Planning Secretariat, Batticaloa Kacheri, 2018). A Tamil respondent from Kokkaddichola states:

"NGOs helped us a lot in comparison with the government. They came in search of those affected by the civil war and rendered their enormous support towards us from housing to psycho-social needs such as counselling. They were so generous; however, due to stringent rules enforced upon those NGOs functioning in our areas by the Defence ministry of then government, they subsequently phased out" (Interview 06).

The above response clearly demonstrates the level of engagement of NGOs in the war affected areas; they appeared to have stretched their support at optimum level in order to improve the living condition of affected people. 


\subsection{Support/Assistance received from government and other agencies for women empowerment}

Women affected by civil war received so much support/assistance from various agencies for their empowerment in the post war context. The following table explains the kind of support women received for their empowerment.

Table 5.5.1: Support/assistance provided for women empowerment in the post war context

\begin{tabular}{|l|c|c|c|}
\hline Row Labels & Tamils & Muslims & Overall \\
\hline Educational assistance & $12.70 \%$ & $23.16 \%$ & $35.86 \%$ \\
\hline Livelihood assistance & $21.11 \%$ & $17.21 \%$ & $38.32 \%$ \\
\hline Dry rations & $19.26 \%$ & $6.35 \%$ & $25.61 \%$ \\
\hline Psycho-social counselling & $5.33 \%$ & $12.09 \%$ & $17.42 \%$ \\
\hline Micro credit loans & $30.53 \%$ & $13.93 \%$ & $44.47 \%$ \\
\hline Capacity building on gender equality & $1.64 \%$ & $9.02 \%$ & $10.66 \%$ \\
\hline Health assistances & $8.61 \%$ & $\mathbf{2 2 . 7 5} \%$ & $31.35 \%$ \\
\hline "Others" & $\mathbf{2 . 4 6 \%}$ & $0.00 \%$ & $\mathbf{2 . 4 6 \%}$ \\
\hline
\end{tabular}

"Others" category includes: Samurthi loans.

As can be seen, $44.47 \%$ respondents received micro credit loans as the major support for women empowerment. Most importantly, majority of Tamil respondents (30.53\%), compared to Muslims, received such support for women empowerment. Responses from interviews and FGDs underline that this is true in the areas dominated by Tamil population in the district where many financial institutions that mushroomed in the post war context have trapped women by offering micro credit loans for self-employment/investment on high interest. Nevertheless, it shows that some women obtained micro credit loans for self-employment/investment on high interest committed suicides to avert backlash or humiliation in the society as they have had no other means of settling the loans back. A Tamil respondent from Ollikkolam avers:

"Many people in our area are trapped by the loans offered by micro-credit financial institutions. They offer even 10,0oo for self-initiatives in the name of self-employment. Pathetically, some of our women end up committing suicides as they have no alternatives to pay back such loans" (Interview 07)

As can be seen, some women obtained micro-credit loans from financial institutions appeared to have committed suicides as they had no means of settling the loans back to financial institutions in time. This is a new trend in the post war scenario, particularly in areas dominated by Tamils in the district. On the contrary, the responses of qualitative data show that this trend is not pervasive among the Muslims in the district, as they are averse to micro-credit loans with obtaining loans from financial institutions on interest being prohibited in Islam.

Meanwhile, women have also received educational assistance (35.86\%), livelihood assistance $(38.32 \%)$, health assistance (31.35\%) and dry rations (25.61\%) too. It is notable that Muslim women, in comparison with Tamil women, have received more educational, livelihood, and health support based on the analysis of survey. The issue of Muslim women obtaining more support from the government in terms of education, livelihood, housing and health has triggered a lot of debates among the Tamil respondents in the district.

"As Muslims politicians in the district are affiliated with the government as Cabinet Ministers or Deputy Ministers, they tend to provide more support to their people and women (Muslims) and thus ignore the Tamil people and women in this regard. However, as our representatives (Members of Parliament) are in the opposition, they are unable to do anything concrete or development activities to our people and women in the district. This is deplorable and sickening" (Interviews o8). 
The above-mentioned perspective is rampant among the respondents from Tamil community in the district when FGD was conducted. They subscribe that Muslim people and women in the district are the most beneficiary of government assistant/support with the backing of their ministers, while Tamils including their women tend to receive less support from the government.

On the contrary, Muslim respondents in the FGDs and interviews dispute by saying that Tamils tend to obtain more support from NGOs that usually overlook Muslims. This argument can be corroborated by the statement of a Muslim respondent Kattankudy.

"NGOs do not come to us and provide us relief or any other assistance in the post war scenario. Whereas, they go to Tamil areas and give them a lot. This is precisely because of their impression that we are not as affected as they think in the civil war. But we were also affected seriously. This is purely a discrimination." (Interview 09).

The point of discrimination shown by NGOs towards Muslims in the district is also raised by participants both in the FGDs and interviews conducted in Muslim areas in the district. Therefore, the scenario in terms of providing relief and other support in the district to both Tamils and Muslims has triggered debates and tensions. While Tamils raising the point of discrimination shown by the government in terms of providing supports to war affected Tamil people in the district, Muslims also raised the same point of discrimination shown by the NGOs to war affected Muslim people in the district. Nevertheless, the support provided by the state and non-state sectors for women empowerment has been as effective as anticipated. The figure given below clearly depicts the effective level of such support.

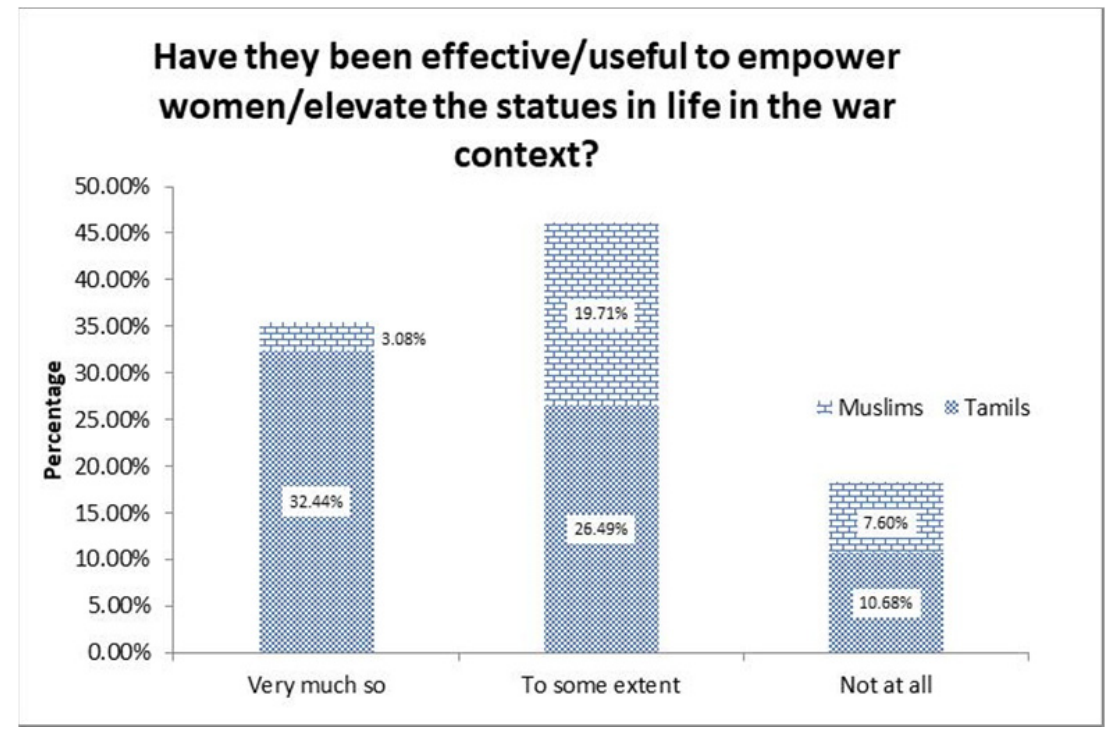

Figure 5.5.1: Level of effectiveness of support provided to women empowerment in the post-war context

The above table illustrates that a large majority of respondents agree that the support provided by various agencies for women empowerment has been useful or effective to both Tamils and Muslims in the district. It is notable that only a negligible number of respondents (18.28\%) have said negatively. The dimension of effectiveness of support/assistance provided by many agencies for women empowerment has been central in the discussion of interviews and FGDs held in the districts. 
Many respondents in both interviews and FGDs endorse that it has been so effective to the extent that it has made some women in the area economically independent. Some respondents pointed out:

"As a result of financial assistance provided by the NGO in the post war situation, I established a small shop that sells daily needs of home. This has earned me some amount of income to run my family smoothly as I am also a divorcee and have few kids" (Interview 10)

"I engage in horticulture at my land because of the financial support extended by NGOs in the post war scenario and have been able to earn some money to lead a decent life with my family in the area" (Interview 06)

The above responses of Tamil women in the district underline that the support provided by NGOs in the post war context have somehow empowered women in terms of their livelihood. This has been endorsed many of the participants of FGDs in the district. This is an interesting finding as far as the study is concerned.

Meanwhile, the survey results show that the support extended by many agencies including the government and NGOs has contributed to women empowerment in many ways as shown below in the table.

Table 5.5.2: Kind of women empowerment due to support provided in the post war context

\begin{tabular}{|c|c|c|c|}
\hline Row Labels & Tamils & Muslims & Overall \\
\hline They are employed in public sector & $1.55 \%$ & $5.15 \%$ & $6.70 \%$ \\
\hline Employed in private sector & $1.29 \%$ & $9 \cdot 79 \%$ & $11.08 \%$ \\
\hline Self-employed & $54.90 \%$ & $22.42 \%$ & $77 \cdot 32 \%$ \\
\hline Lead a decent life & $29.38 \%$ & $8.76 \%$ & $38.14 \%$ \\
\hline Psychologically and morally empowered & $10.82 \%$ & $10.05 \%$ & $20.88 \%$ \\
\hline They are empowered in terms of sexual and gender discrimination & $4.90 \%$ & $7.22 \%$ & $12.11 \%$ \\
\hline Benefitted in the health sector immensely (hospital, $\mathrm{MOH}$ constructed) & $3.87 \%$ & $5.41 \%$ & $9.28 \%$ \\
\hline Level of schooling of women has increased tremendously & $9.02 \%$ & $11.86 \%$ & $20.88 \%$ \\
\hline Others & $0.77 \%$ & - & $0.77 \%$ \\
\hline
\end{tabular}

The above table of survey results suggests that the support provided by the agencies to women empowerment help contributed to women's self-employment (77.32\%), enable them to lead a decent life (38.14\%), psychologically and morally empowered women (20.88\%) and the increase of schooling of women.

As discussed above, the support provided by various agencies for women empowerment help consolidated their self-employment ensuring them to lead to a decent life. Of the various agencies, women prioritized NGOs as the most important entities that helped restore their lives in terms of their economic means and livelihood. This can be considered as a positive contribution made by various agencies, particularly the NGOs in the post war context of Sri Lanka in the district.

\subsection{Support/Assistance received by women in the present context of Sri Lanka}

It is necessary to focus whether or not the support provided by agencies in the post war context continues to be provided in the current context of Sri Lanka, since war ended exactly a decade ago. It is no surprising that the support has not extensively continued to be provided to women empowerment in the current context of Sri Lanka. The following figure shows it. 


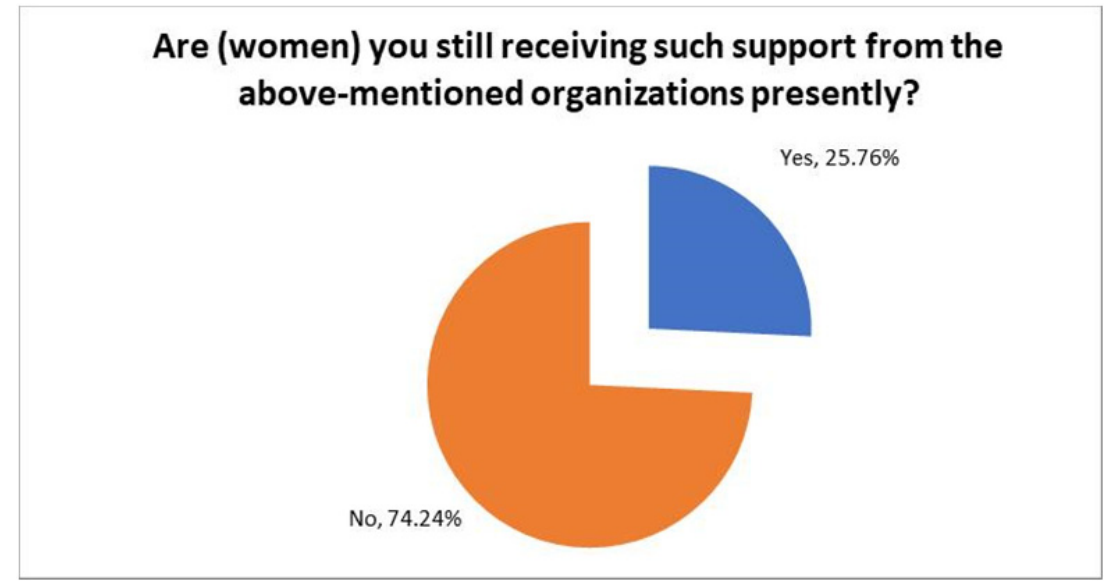

Figure 5.6.1: Support received by women in the current context

The above figure explains the scenario clearly that the support provided by state and non-state sectors for women empowerment has significantly ceased (74.24\%) in the current context. This position has strongly been emphasized by the qualitative data obtained in the district too. The survey results of the trend can be shown as below in the table.

Table 5.6.1: Support received by women in the current context of Sri Lanka

\begin{tabular}{|l|c|c|c|}
\hline $\begin{array}{l}\text { Are (women) you still receiving such support from } \\
\text { the above-mentioned organizations presently? }\end{array}$ & Tamils & Muslims & Overall \\
\hline Yes & $10.95 \%$ & $14.81 \%$ & $\mathbf{2 5 . 7 6 \%}$ \\
\hline No & $58.82 \%$ & $15.42 \%$ & $74.24 \%$ \\
\hline Grand Total & $\mathbf{6 9 . 7 8} \%$ & $\mathbf{3 0 . 2 2} \%$ & $\mathbf{1 0 0 . 0 0 \%}$ \\
\hline
\end{tabular}

As can be seen, women representing Tamils (58.82\%) and Muslims (15.42\%) state that they are not personally receiving any support from various agencies currently. The survey results suggest that the government is no more interested in providing such supports to women (45.36\%), UN organizations and NGOs have phased out/ceased their operation (56.28\%), and Priority of CBOs and other civil society organizations has shifted now $(26.23 \%)$. This can be shown in a table below:

Table 5.6.2: Challenges in accessing to assistance provided by various agencies currently to women empowerment

\begin{tabular}{|l|c|c|c|}
\hline $\begin{array}{l}\text { If no, what obstacles are there now to access to such support/assistance } \\
\text { provided those institutions, especially for women (Select all that apply)? }\end{array}$ & Tamil & Muslim & Overall \\
\hline Government is no more interested in providing such supports to women & $27.32 \%$ & $18.03 \%$ & $45.36 \%$ \\
\hline UN organizations and NGOs have phased out/ceased their operation & $41.80 \%$ & $14.48 \%$ & $56.28 \%$ \\
\hline Priority of CBOs and other civil society organizations has shifted now & $19.13 \%$ & $7.10 \%$ & $26.23 \%$ \\
\hline Role of Women has been confined to household chores by society & $0.27 \%$ & $9.29 \%$ & $9.56 \%$ \\
\hline Others & $4.10 \%$ & $0.55 \%$ & $4.64 \%$ \\
\hline
\end{tabular}

As discussed above, a majority of respondents in the interviews and FGDs have subscribed that little support is currently provided by the government, NGOs and UN organizations. They illustrate that priority of the state and non-state sectors have shifted to some other areas and argue that most 
of the NGOs have phased out currently in the district. Some respondents have pointed out that the government currently tends to provide houses to those who deserve in the district on a loan basis or prior financial commitment by the owners of the houses. Thus, they argue that nothing is given free to those affected by the war in the current context of Sri Lanka in the district.

Moreover, of the total survey respondents that stated affirmatively on the assistance provided by agencies for women empowerment currently, only a quarter of them (25.76\%) have subscribed that such support continues to be provided by various agencies currently. However, although this is insignificant, the survey suggests that micro credit loans (65.35\%), health assistance (64.57\%), livelihood assistance (59.06\%), educational assistance (50.39\%) and psycho-social counselling (56.69\%) continue to be provided by various agencies in terms of women empowerment in the current context of Sri Lanka.

It is interesting that majority of respondents in the survey representing Tamils and Muslims stated that they would like to have the assistance of women empowerment continued by various agencies. This can be shown in a figure given below.

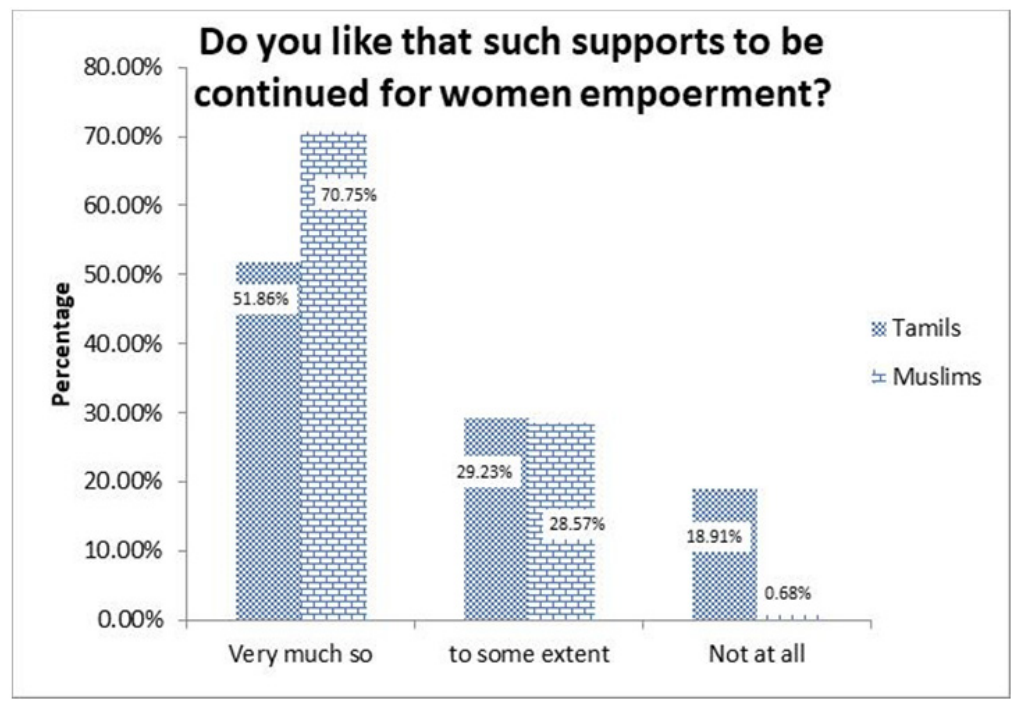

Figure 5.6.2: Expectation of support to women empowerment by various agencies

The above table shows that both Tamil (51.86\% \& 29.23\%) and Muslim respondents (70.75\% and $28.57 \%$ ) have stated that assistance by various agencies for the purpose of women empowerment be continued and only a negligible number of respondents have discounted the proposition. A majority of respondents-both Tamils and Muslims in the interview and FGDs have also endorsed that the support provided by various agencies to women empowerment needs to be sustained and continued in the district.

\section{Conclusion}

In conclusion, as the people suffered immensely due to the protracted war in the district, they received much support such as housing assistance, dry rations, livelihood assistance, micro-credit loans and psycho-social counselling from state and non-state sectors in the post war period in the Batticaloa district of Eastern Province. Moreover, women have also received educational, livelihood, health assistance, and dry rations for their empowerment. Nevertheless, Tamil women, compared to Muslim women, received less educational, livelihood, and health support from the government, since 
Tamil politicians are in the opposition without being affiliated with the ruling party and thus could not do anything to their community or women. Whereas Muslim women in the district have received much support from the government since Muslim politicians are affiliated with the ruling political party and thus they rendered much support towards their community, particularly to women for their empowerment in the district. However, it is notable that Tamils received more support from NGOs than the Muslims in the district. It is also worth mentioning that the support of micro credit loans Tamil women obtained from financial institutions on high interest for self-employment as part of their empowerment has apparently trapped them in the district leading to a number of suicides by Tamil women due to humiliation or in fear of backlash, as they had no other means to settle back their loans taken from such financial institutions on high interest. However, this trend is not pervasive among Muslim women in the district, as they are averse to micro-credit loans from banks on high interest.

It is also clear that the support provided by various agencies for women empowerment-both Tamil and Muslims in the district has been useful or effective as it contributed to women's selfemployment leading to their decent life, making them psychologically and morally empowered and ensured high women's literacy in the district in the post war context. Nevertheless, such supports to women have significantly ceased, as the government is no more interested in providing such supports to women, UN organizations and NGOs have phased out/ceased their operation, and priority of Community Based Organizations and other civil society organizations has shifted now. Most importantly, a vast majority of people representing Tamils and Muslims now request that such assistance to women empowerment be continued in the district.

Therefore, the impact of socio-economic development initiatives undertaken by the government, NGOs and UN organizations on women empowerment has been extremely productive to the extent that it has empowered their financial status and livelihood. It has also made a significant contribution to their educational, health and other aspect of improvement in the post war context in the district. However, it is unfortunate that since a majority of such institutions have now ceased their operation in terms of women empowerment initiatives, a significant number of women in the district suffer a lot in terms of rebuilding livelihood. Thus, it is important that these organizations focus their attention in future on building the capacity of women by developing their knowledge and skills, and providing financial assistance for their self-employment on a soft loan basis or under a grant scheme.

\section{Acknowledgement}

This study received grants from the British Council, Sri Lanka, under TRANFORM Edinburgh Napier University Project.

\section{Reference}

Barakat, S. (2005) After the conflict: Reconstruction and redevelopment in the aftermath of war. London: I.B. Tauris. Central Bank of Sri Lanka (2014) Annual Report-2014, Central Bank of Sri Lanka, Colombo: CBSL

District Secretariat, Planning Division, Statistical Handbook (2014). District Secretariat, Batticaloa.

Ismail, SMM, (2016) Post-war Socio-economic Development in the Eastern Province: A Case Study of Ampara District. Kalam, International Journal of Faculty of Arts and Culture, South Eastern University of Sri Lanka, Vol. VI (o1): 176-182

Kelegama, Saman, (2011). Socio Economic Challenges of Post Conflict Reconstruction in Sri Lanka. Publication of Institute of Poverty Studies, www.ips.lk

Ozerdem, Alpazan.(2007). Consolidating peace after war: Challenges of reconstruction and peacebuilding: Responding to conflict.

Sutharsan, S. (2014). Post - War Socio Economic Development in the Eastern Province of Sri Lanka (Batticaloa \& Trincomalee districts), Proceedings of $4^{\text {th }}$ International Conference, Eastern University of Sri Lanka 
Thalpawila, Osantha Nayanapriya. (2016). Post -War Reconstruction in Sri Lanka: Reconstruction and Development of the Socio-Economic Sectors. International Journal of Liberal Arts and Social Science, Vol 4(05): $43-56$

United Nations (2009). Report of the Secretary General on peacebuilding in the immediate aftermath of conflict. New York: United Nations.

\section{Appendix I: Details Of Interviewees}
o1. Interview $\mathrm{No}-\mathrm{o} 1$
02. Interview $\mathrm{No}-\mathrm{O} 2$
03. Interview $\mathrm{No}-\mathrm{O} 3$
04. Interview $\mathrm{No}-\mathrm{O} 4$
05. Interview $\mathrm{No}-05$
o6. Interview No-o6
o7. Interview $\mathrm{No}-\mathrm{o} 7$
o8. Interview $\mathrm{No}-\mathrm{o} 8$
o9. Interview $\mathrm{No}-09$
10. Interview $\mathrm{No}-10$
11. Interview No - 11
12. Interview $\mathrm{No}-\mathbf{1 2}$
13. Interview $\mathrm{No}-13$
14. Interview No - 14
15. Interview No -15

Kattankudy

Puliyenthivu

Eravur

Ollikkolam

Kattankudy

Kokkaddichola

Ollikkolam

Kokkaddichola

Kattankudy

Kaluwanchikkudy

Batticaloa DS office

Kattankudy

Pattipalaia DS office

Arayampathy

Kaluwanchikkudy
Housewife

Housewife

Self-employed woman

Housewife

Civil activist

Housewife

Housewife

Housewife

Housewife

Housewife

Women Development Officer

Women Development Officer

Women Development Officer

Women Development Officer

Civil activist 